\title{
Article \\ The Evolution of Intumescent Char in Flame-Retardant Coatings Based on Amino Resin
}

\author{
Wei Song, Muting Wu (D), Yanrong He, Yuzhang Wu and Wei Qu * \\ Research Institute of Wood Industry, Chinese Academy of Forestry, Xiangshan Road, Beijing 100091, China; \\ sw@caf.ac.cn (W.S.), wmt1996@caf.ac.cn (M.W.), 18600991247@163.com (Y.H.), wyz@caf.ac.cn (Y.W.) \\ * Correspondence: wqu@caf.ac.cn
}

Citation: Song, W.; Wu, M.; He, Y.; $\mathrm{Wu}, \mathrm{Y}$; $\mathrm{Qu}, \mathrm{W}$. The Evolution of Intumescent Char in Flame-Retardant Coatings Based on Amino Resin. Coatings 2021, 11, 709. https:// doi.org/10.3390/coatings11060709

Academic Editor: Maude Jimenez

Received: 27 May 2021

Accepted: 9 June 2021

Published: 12 June 2021

Publisher's Note: MDPI stays neutral with regard to jurisdictional claims in published maps and institutional affiliations.

Copyright: (c) 2021 by the authors. Licensee MDPI, Basel, Switzerland. This article is an open access article distributed under the terms and conditions of the Creative Commons Attribution (CC BY) license (https:// creativecommons.org/licenses/by/ $4.0 /)$.
Abstract: Intumescent flame-retardant (IFR) coatings have been gaining more attention. The behaviors of intumescent char in IFR coatings play the most important role in its flame-retardant properties. However, the evolution of intumescent char throughout the whole process of protection is still unclear. In this study, both the formation and shrinkage of char were studied. The formulation of IFR includes melamine modified urea-formaldehyde resin (MUF), ammonium polyphosphate (APP) and pentaerythritol (PER). The flame-retardant properties of the coating were measured by the cone calorimeter (CONE). The evolution of the volume and the pore size distribution of char were monitored. The morphological and chemical structures were characterized by the scanning electron microscopy (SEM) and Fourier transform infrared spectroscopy (FTIR). The results show that the evolution of intumescent char could be divided into three stages. More than $50 \%$ shrinkage of char occurs in the second stage. There are obvious transformations of the morphological and chemical structures of char between the different stages.

Keywords: intumescent flame-retardant coatings; intumescent char; char formation; shrinkage; pore size distribution

\section{Introduction}

The intumescent flame retardant (IFR) coating is a convenient, efficient and economical means to protect physical properties of underlying material [1]. The APP-PER-MEL system, including ammonium polyphosphate (APP), pentaerythritol (PER), and melamine (MEL), is the most commonly used formulation of IFR. The mechanisms of char formation and flame retardancy of the APP-PER-MEL system have been studied widely [2-4]. In the event of a fire, the coating expands on contact with heat to provide a thermally insulating char that delays diffusion of heat to substrates [5]. The properties of flame-retardant coatings depend on the quality of the intumescent char [6,7]. The addition of chicken eggshell to the traditional APP-PER-MEL system can improve the flame retardancy and smoke suppression, which is ascribed to the formation of a more compact, thermally stable, and intumescent char [8]. The well-distributed nano- $\mathrm{SiO}_{2}$ particles of the flameretardant system could modify char formation and anti-oxidation of char structure at high temperatures [9].

The flame-retardant performance of the coating is influenced largely by the matrix resins [3]. The polyacrylate, epoxy, and melamine-formaldehyde resins (MF) have been widely investigated in commercial intumescent coatings [10]. Apart from the matrix resin, melamine-formaldehyde resins also work as the gas source in this system with a high expansion factor [11]. Urea-formaldehyde resin (UF) is another kind of amino resin that is widely used in paper, textiles and industrial wood. UF could be modified by melamine (MUF) during the condensation to reduce the amount of free formaldehyde and increase bonding strength and water resistance [12]. Compared with MF resins, MUF resins have a lower cost and better storage stability, which is important for the wood industry. The flame-retardant performance of the mixture of APP and MUF was studied in our previous 
work [13]. The flame-retardant performance of samples is closely related to the amount of APP. To improve its flame-retardant performance and lower the cost, the coating containing APP, PER, and MUF should be prepared and its mechanism needs to be fully investigated.

The expansion height or volume of char is the key parameter to test the IFR coating, which gains much of the attention in IFR coating research [14]. To date, the majority of previous research into the behavior of intumescent coatings has mainly been focused on understanding the effects of different formulations to pass the standard fire resistance rating test [15-17]. Models are established to predict the expansion ratio of IFR coatings [18]. Compared with char formation, the crack and shrinkage of char play more important roles in the properties of coatings. Some nanoparticles [19,20] and fibers [21,22] are used to prevent the formation of cracks and shrinkage of char. However, the evolution of intumescent char in the APP-PER-MEL system, the base of optimization is still unclear.

In this work, a kind of flame-retardant coating is prepared based on amino resin. The important parameters of char were investigated in the processes of char formation and shrinkage, including intumescent volume, pore size distribution, morphology, chemical structures, and flame retardancy. The cell structures of char were characterized by scanning electron microscopy (SEM) and digital camera. Fourier transform infrared spectra (FTIR) was used to show the chemical structure of char. The flame retardancy was characterized by the cone calorimeter (CONE). It is the object of the present research to study the evolution of intumescent char, which is very important to improv the flame-retardant performance of coatings.

\section{Materials and Methods}

\subsection{Materials}

Ammonium polyphosphate (APP, $\mathrm{n}$ (degree of polymerization) $>1000$ ) was purchased from Sichuan Changfeng Chemical Co., Ltd. Pentaerythritol (PER), melamine, urea, and formaldehyde solution ( $37 \%-40 \%$ ) were purchased from Beijing modern eastern fine chemical Co., Ltd. Medium density fiberboard (MDF) was supplied by Shijiazhuang Huajie Wood Co., Ltd. All materials were used as received.

\subsection{Sample Preparation}

MUF resin: First, $120 \mathrm{~g}$ formaldehyde solution (37\%) and $40 \mathrm{~g}$ urea were mixed in a reactor equipped with a thermometer and mechanical stirrer, and the $\mathrm{pH}$ was adjusted to 8.0-9.0 with $1 \mathrm{M} \mathrm{NaOH}$. The mixture was heated to $90{ }^{\circ} \mathrm{C}$ in $35 \mathrm{~min}$. Then, the $\mathrm{pH}$ was adjusted to 5.0-5.5 with $\mathrm{NH}_{4} \mathrm{Cl}$, followed by the addition of $15 \mathrm{~g}$ urea and $10 \mathrm{~g}$ melamine for $40 \mathrm{~min}$ with the $\mathrm{pH}=8.5$. The $\mathrm{pH}$ value of MUF is 7.0-7.5. The viscosity of MUF at $25^{\circ} \mathrm{C}$ is $\mathrm{ca} .35 \mathrm{mPa} \cdot \mathrm{s}$.

Flame-retardant resin (A3P1): The flame-retardant resin was prepared by mixing the $30 \mathrm{~g}$ APP, $10 \mathrm{~g}$ PER, and $100 \mathrm{~g}$ MUF with fully stirring by the rotary agitator for $5 \mathrm{~min}$.

Coated MDF: The coated MDF samples (for CONE) were prepared through two steps. Firstly, the flame-retardant resins (coating weight $=333 \mathrm{~g} / \mathrm{m}^{2}$ ) were coated on the surface of MDF $(100 \mathrm{~mm} \times 100 \mathrm{~mm} \times 15 \mathrm{~mm})$. Secondly, the coated MDF were dried at room temperature for $24 \mathrm{~h}$ to cure the coating.

Coated steel: The coated steel samples were prepared like the coated MDF. The size of the steel was $80 \mathrm{~mm} \times 80 \mathrm{~mm} \times 2 \mathrm{~mm}$.

\subsection{Characterization}

Thermogravimetric analysis (TGA) was performed by using an SDT Q600 thermal analyzer (TA Instruments, New Castle, DE, USA). A $3 \mathrm{mg}$ sample was placed in an alumina crucible with a heating rate of $10^{\circ} \mathrm{C} / \mathrm{min}$ under air atmosphere, with the flowing $50 \mathrm{~mL} / \mathrm{min}$, from $30^{\circ} \mathrm{C}$ to $800{ }^{\circ} \mathrm{C}$.

In order to form char, steel samples coated with $\mathrm{A} 3 \mathrm{P} 1$ resin were heated in the muffle furnace at $800{ }^{\circ} \mathrm{C}$ and stopped at a certain time $(15 \mathrm{~s}, 20 \mathrm{~s}, 25 \mathrm{~s}, 30 \mathrm{~s}, 40 \mathrm{~s}, 50 \mathrm{~s}, 60 \mathrm{~s}, 90 \mathrm{~s}$, $120 \mathrm{~s}$ and $180 \mathrm{~s})$. The volume of char was measured by the drainage method with paraffin 
embedding to reinforce the char structure and insulate the water. Every sample was measured three times. The pore size distribution and morphology of char were monitored by a digital camera and the scanning electron microscopy (SEM, S4800, Hitachi, Tokyo, Japan). The SEM was used at high vacuum conditions with a voltage of $10 \mathrm{kV}$. Before SEM observation, all samples were gold-sputtered to improve their conductivity.

Images of the char in a cross-section view were further analyzed by Image J. The main provisions of the methodology were from the modification of the work of Nedryshkin and colleagues [11] The pores and the cell wall were distinguished by the gray level. The size and number of pores was calculated by counting the number of pixels. The diameter of the pore was calculated from the circle of equal area. Firstly, the char was sliced with a sharp knife, and then the cut char was put in the photo room with the LED light. The ISO of the camera (Sony A7, Tokyo, Japan) was adjusted to 800 with the shutter speed 1/200 s. The captured image was originally output with $6000 \times 4000$ pixels. To eliminate image error, the image was pooled to $200 \mathrm{dpi}$ and further output to the same width images of 360 pixels. Secondly, Image J software was used to make the separation of pores and cell walls. The images were transferred into 8 bits with 4.5 pixel as $1 \mathrm{~mm}$.

Fourier transform infrared spectra (FTIR) of A3P1 resin and char from steel samples were recorded by using Nicolet iS50 (Thermo Fisher Scientific, Madison, WI, USA) from 400 to $4000 \mathrm{~cm}^{-1}$. The rate of the differentiate was $4 \mathrm{~cm}^{-1}$ and the number of scanning was 8.

The flame-retardant performance of MDF coated with A3P1 resin was tested by the cone calorimeter (CONE, Toyoseiki, Tokyo, Japan according to ISO 5660-1 [23] under an external heat flux of $50 \mathrm{~kW} / \mathrm{m}^{2}$. Three replications were performed for each MDF type.

\section{Results}

\subsection{Flame-Retardant Properties}

The flame-retardant properties of MDF coated with A3P1 resin were measured by CONE. Figure 1 shows heat release rate (HRR) and total heat release (THR) of samples by time. There was a sharp peak in the HRR curve of MDF, with the peak value $270 \mathrm{~kW} / \mathrm{m}^{2}$, which was similar to the results of Park and colleagues [24]. As for A3P1 coated samples, the peak values of HRR became lower and lower, and the peak time was shifted along with the increase in the coating weight. When the coating weight was $400 \mathrm{~g} / \mathrm{m}^{2}$, the peak of HRR almost disappeared. The coated MDF cannot be flamed, even with a spark, so there was almost no heat release until the intumescent char cracks. The flammable volatiles were released from the cracks, and then the samples started to burn with a flame [25]. The coating weight was higher and the no-crack time of samples was longer because of their better insulation properties. When the coating weight was more than $250 \mathrm{~g} / \mathrm{m}^{2}$, the total heat release (THR) of samples was lower than $8 \mathrm{MJ} / \mathrm{m}^{2}$ in $10 \mathrm{~min}$. THR in $600 \mathrm{~s}$ was decreased by $74 \%$ when the coating weight was $400 \mathrm{~g} / \mathrm{m}^{2}$, compared with that of the pure MDF. According to the Building Standard Law of Japan, samples with a coating weight of more than $250 \mathrm{~g} / \mathrm{m}^{2}$ satisfy Class II, a seminon-combustible material [26]. It indicates that $\mathrm{A} 3 \mathrm{P} 1$ is an effective flame-retardant coating for wood materials and that the crack in the char is a key factor for the failure of coatings. The study of the evolution of intumescent char is significant for flame-retardant coatings.

\subsection{Thermal Analysis}

The thermal degradation of resins was studied by TGA. Figure 2 shows the TG and DTG curves of the A3P1 resin and its components. The degradation of PER was at a narrow range between $240^{\circ} \mathrm{C}$ and $380{ }^{\circ} \mathrm{C}$, without char left at $400{ }^{\circ} \mathrm{C}$. The degradation temperature $\left(\mathrm{T}_{5 \%}\right)$ of APP was $340{ }^{\circ} \mathrm{C}$, with $16 \%$ residue left at $800{ }^{\circ} \mathrm{C}$. It was found that MUF resin started to decompose at $174{ }^{\circ} \mathrm{C}$ and there was almost no char residue left at $800^{\circ} \mathrm{C}$. The final char residue ratio of $\mathrm{A} 3 \mathrm{P} 1$ resin was $23 \%$ at $800{ }^{\circ} \mathrm{C}$, more than that of any single component. The shift of decomposition peak from $324^{\circ} \mathrm{C}$ to $279{ }^{\circ} \mathrm{C}$ was due to the catalysis 
effect of the decomposed APP compound on the MUF resin. In spite of this, the volatile generated from A3P1 was lower than that of the MUF resin [3].
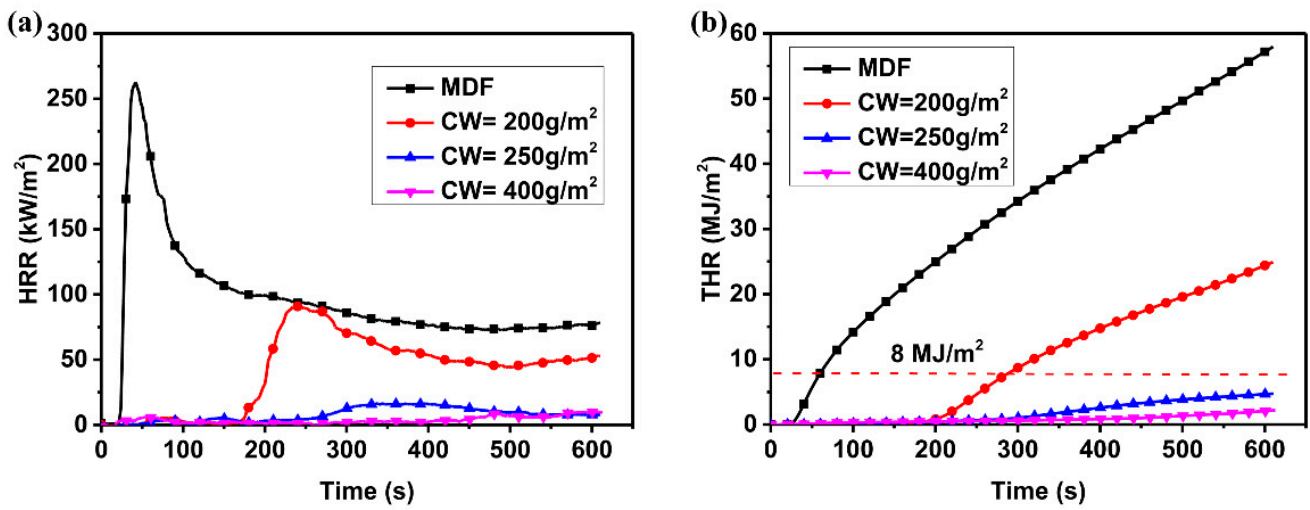

Figure 1. HRR (a) and THR (b) of MDF and MDF coated by A3P1 with different coating weights.
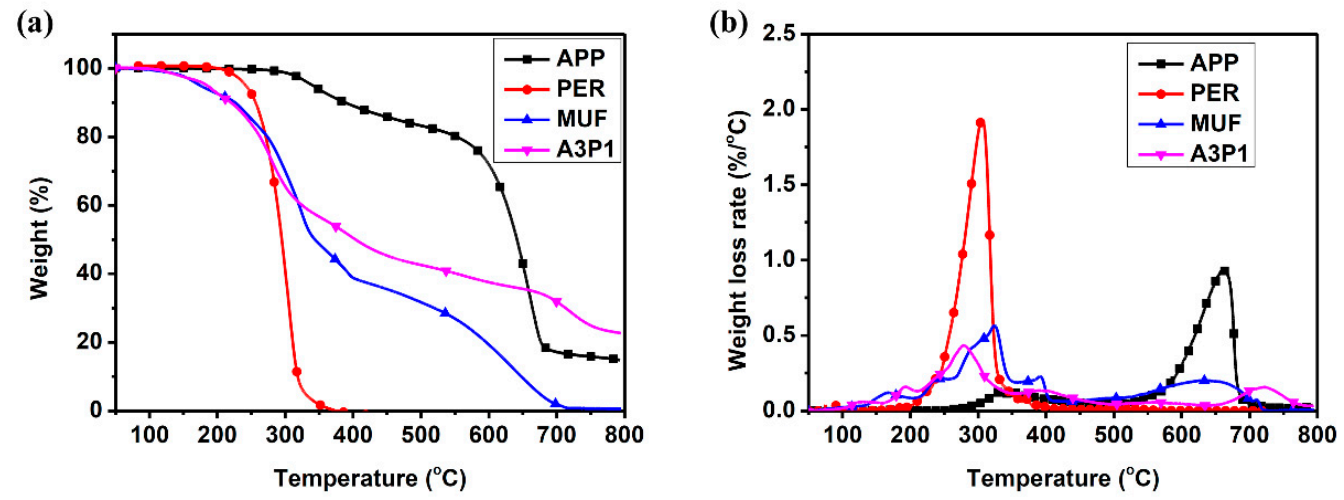

Figure 2. TGA (a) and DTG (b) curves of A3P1 and its components.

As shown in Figure 2b, there were three main peaks in the DTG curve of A3P1 resin. The first band was related to the char formation $\left(200-350^{\circ} \mathrm{C}\right)$. Poly-metaphosphoric acid and pyrophosphoric acid are released after APP degrades and dehydrates. The charring framework was formed by the interaction between PER and acids. At the same time, MUF began to release $\mathrm{NH}_{3}$ gas, which blew the melted resin to form a compact, firm and black charring layer. The weight loss of $\mathrm{A} 3 \mathrm{P} 1$ resin was about $42 \%$ in the char formation. The second peak $\left(350-650^{\circ} \mathrm{C}\right)$ was due to the oxidation of char. The weight loss of A3P1 resin was about $22 \%$. The third peak $\left(650-780^{\circ} \mathrm{C}\right)$ was about the inorganic framework formation with $13 \%$ weight loss [19].

\subsection{Volumes and Pore Sizes of Intumescent Chars}

The volume of intumescent char was one of the key parameters of the IFR coating. The maximum expansion volumes are often measured as an index to evaluate the IFR coatings [27,28]. The volume of intumescent char is measured by the drainage method with paraffin embedding. The whole evolution of char, both char formation and shrinkage, was monitored at $800{ }^{\circ} \mathrm{C}$ in the muffle furnace with the coating weight $333 \mathrm{~g} / \mathrm{m}^{2}$. According to the TGA results, A3P1 could decompose completely at $800{ }^{\circ} \mathrm{C}$. As shown in Figure 3, the expansion and shrinkage of char were observed clearly. The shapes of char were irregular and their surface was smooth and relatively dense. The volume of intumescent char increases first and then decreases. According to the curves in Figure 4, the coating was expanded up to the maximum volume of ca. $127 \mathrm{~mL}$ in the first $30 \mathrm{~s}$. The volume was decreased rapidly to ca. $56 \mathrm{~mL}$ by more than $50 \%$ in the next $60 \mathrm{~s}$. The decrease rate of 
volume was slower after $90 \mathrm{~s}$. As above, the evolution of the volume of intumescent char could be divided into three stages:

1. The char was formed before $30 \mathrm{~s}$;

2. The volume of char decreased rapidly from $30 \mathrm{~s}$ to $90 \mathrm{~s}$;

3. The volume of char decreased slowly after $90 \mathrm{~s}$.

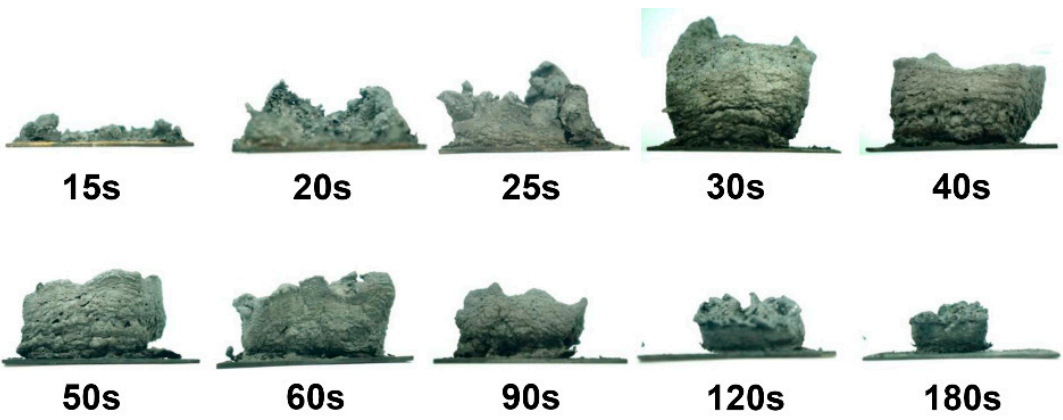

Figure 3. Optical images of $\mathrm{A} 3 \mathrm{P} 1$ resins coated on the steel at $800{ }^{\circ} \mathrm{C}$ with heating time from $15 \mathrm{~s}$ to $180 \mathrm{~s}$.

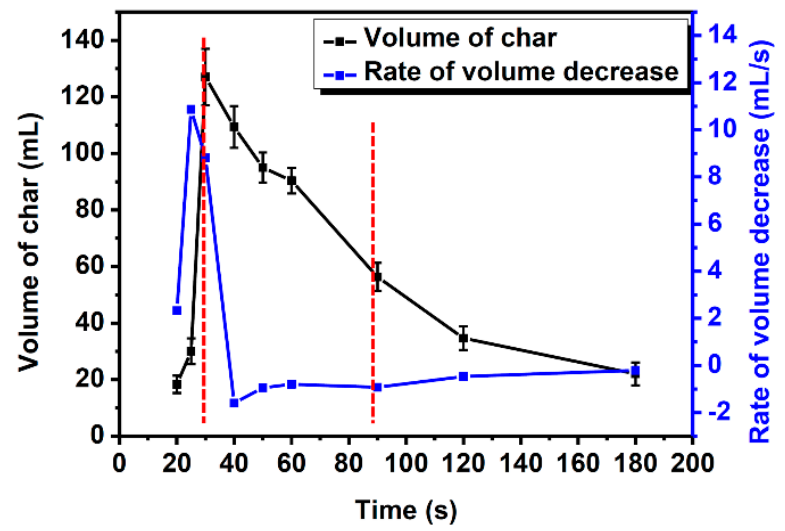

Figure 4. The curves of the volume of char and the rate of volume decrease in A3P1 resins.

The shrinkage over $50 \%$ occurred in the second stage, where the crack in the char is most likely to develop. Once the crack appears, the IFR coating will fail. We can infer that the decrease in the shrinkage in the second stage may be a new method to improve the flame-retardant properties of coatings. The shrinkage of the char in the second stage could be a parameter of IFR coatings.

The thermal conductivity of intumescent char depends on the size and location of the pores [11]. The fire-retardant efficiency of IFR coating is influenced by the evolution of the pore dimensions. The images of the char in a cross-sectional view are shown in Figure 5 . The trend of the pore percentage is very similar to that of the volume of char in Figure 4. The structure of the char becomes denser after $30 \mathrm{~s}$. The histograms of pore size distributions are shown in Figure 6. Compared to the char at $20 \mathrm{~s}$, more pores are developed in the next $10 \mathrm{~s}$, especially big pores ( $\mathrm{D}>5 \mathrm{~mm}$ ). In the second stage (30-90 s), the number of small pores $(\mathrm{D}<1 \mathrm{~mm})$ and medium pores $(\mathrm{D}=1-5 \mathrm{~mm})$ do not change much. However, the number of big pores is decreased sharply. There are no big pores at the end of the second stage. It indicates that the more than 50\% shrinkage of char in the second stage is due to the collapse of the big pores. The properties of flame-retardant coatings may be improved by the decrease in the number of big pores. In the third stage, both the number of small and medium pores are decreased gradually. 


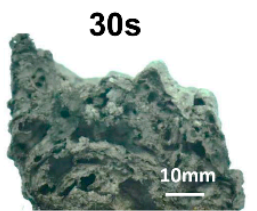

$90 \mathrm{~s}$

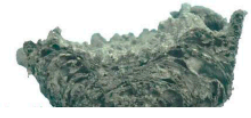

60s

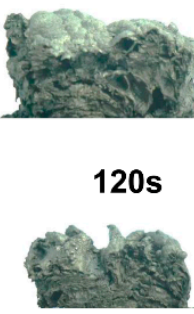

Figure 5. The cross-sectional views of the char at $800^{\circ} \mathrm{C}$ with heating time 30, 60, 90 and $120 \mathrm{~s}$.

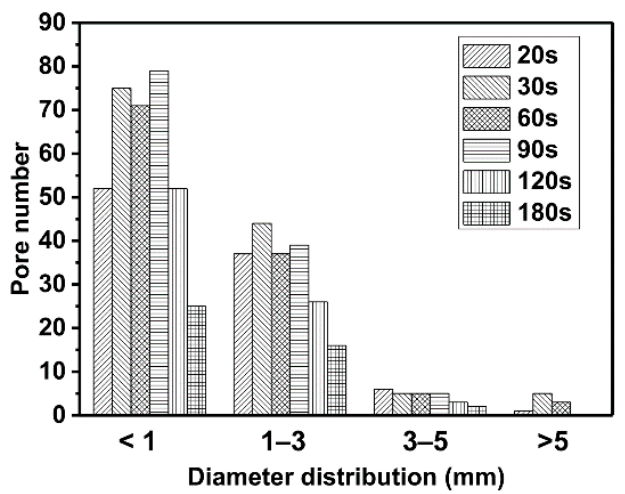

Figure 6. The distribution of the pores of the char at $800^{\circ} \mathrm{C}$ with heating time from $20 \mathrm{~s}$ to $180 \mathrm{~s}$ in a cross-sectional view.

\subsection{Morphological Structures of Intumescent Char}

The SEM test gives some information on the change in the morphological structure of intumescent char with the heating time increasing. The SEM micrographs of the char obtained from A3P1 are presented in Figure 7. The concave bubbles in the image of $20 \mathrm{~s}$ indicate an incomplete expansion with low viscosity [19]. The expansion is completed in $30 \mathrm{~s}$ according to the filled bubbles. The multi-bubble structure of char has a better capacity for insulation [29]. In the second stage (30-90 s), the bigger bubbles are ruptured and the gas in the bubbles is released gradually. The number of small bubbles is decreased and some folds appear. The capacity for insulation in the char is decreased [30]. In the third stage, the bubbles disappear and a sheet structure with a smooth surface is revealed. The morphology of the char is transferred from a multi-bubble structure to a sheet structure in the process of the shrinkage of the char.

\subsection{FTIR Analysis}

The chemical changes of char in this process were investigated by FTIR, as shown in Figure 8. The curve of A3P1 resin shows a strong signal at around $3400 \mathrm{~cm}^{-1}$, which can be attributed to the $(-\mathrm{N}-\mathrm{H}-)$ bonds from the MUF and APP, and the $(-\mathrm{OH})$ from PER [31,32]. The peak at $2950 \mathrm{~cm}^{-1}$ of $(\mathrm{C}-\mathrm{H})$ bond, and the peak at $874 \mathrm{~cm}^{-1}$ of $(\mathrm{P}-\mathrm{O}-\mathrm{P})$, are the typical peaks of APP. In the char formation stage (before $30 \mathrm{~s}$ ), the signal of $(\mathrm{C}-\mathrm{H})$ bond disappeared rapidly and the intensity of the peak at around $3400 \mathrm{~cm}^{-1}$ was decreased gradually. The signal of $\mathrm{P}-\mathrm{O}-\mathrm{P}$ at $874 \mathrm{~cm}^{-1}$ weakened and disappeared after $30 \mathrm{~s}$, indicating that APP was consumed in the char formation stage. The increase in the signal at $1250 \mathrm{~cm}^{-1}$ can be attributed to the newly formed $\mathrm{P}=\mathrm{O}$ band. The signal in $1080 \mathrm{~cm}^{-1}$ may be attributed to the $\mathrm{PO}_{4}$ produced by the decomposition of APP and the newly formed P-N-C bond or $\mathrm{P}-\mathrm{O}-\mathrm{C}$ bond [33]. The newly formed strong peaks from $1630 \mathrm{~cm}^{-1}$ to $1660 \mathrm{~cm}^{-1}$ can be ascribed to the newly formed $\mathrm{C}=\mathrm{C}$ and $\mathrm{C}=\mathrm{O}$ bonds. The new signal at $1409 \mathrm{~cm}^{-1}$ can be ascribed to the newly formed $\mathrm{H}_{3} \mathrm{PO}_{4}$ bonds. In the second stage (30-90 s), the volume of char decreased rapidly. The peak of the $\mathrm{C}=\mathrm{C}$ bond gradually switched to the peak of the 
$\mathrm{C}-\mathrm{H}$ bond of the benzene ring at around $1550 \mathrm{~cm}^{-1}$. The peaks of $\mathrm{H}_{3} \mathrm{PO}_{4}$ bonds gradually disappeared. In the third stage (after $90 \mathrm{~s}$ ), $\mathrm{P}-\mathrm{O}-\mathrm{C}$ bond was formed, whose peak was located at around $1000 \mathrm{~cm}^{-1}$. The peak of N-H bond disappeared after $90 \mathrm{~s}$, indicating that the gas was released completely, which agrees with the results of the SEM.

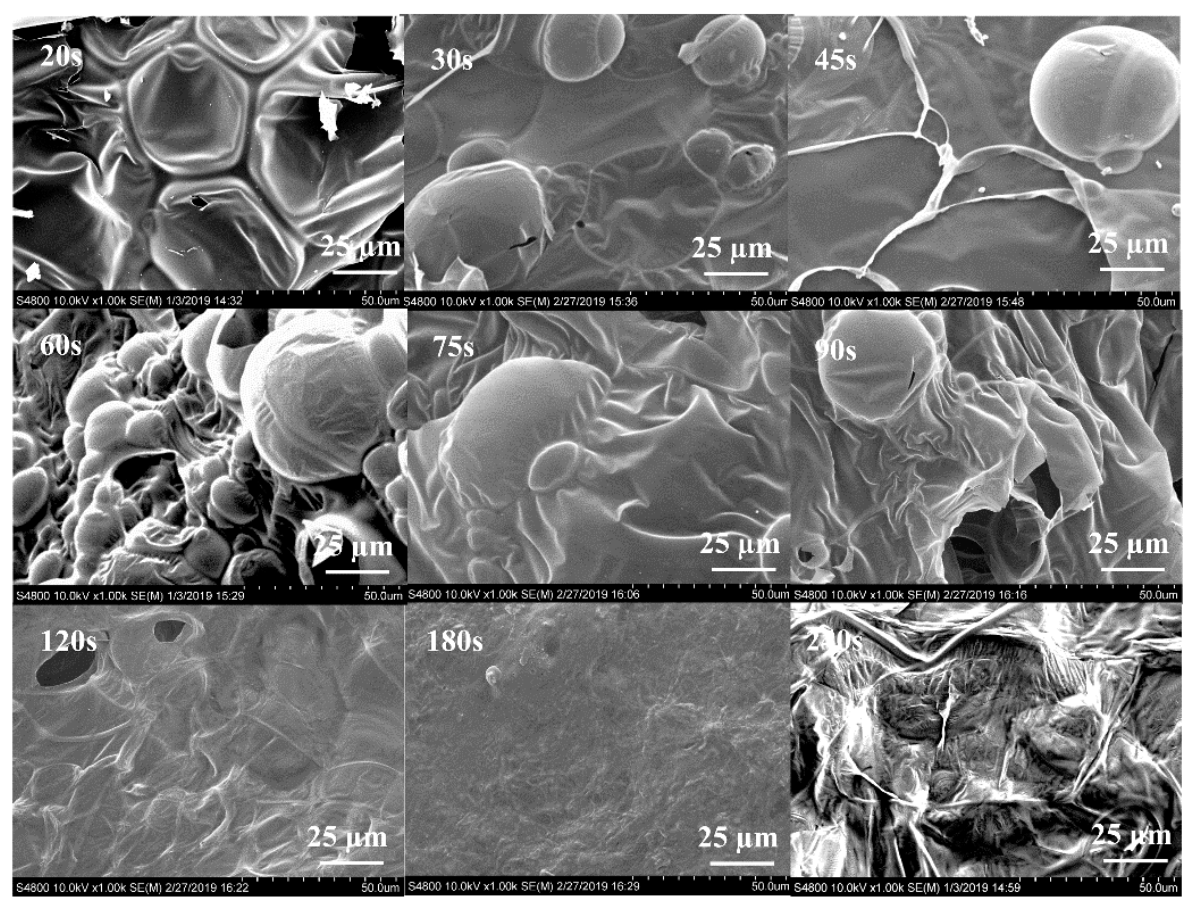

Figure 7. SEM images of char of A3P1 formed at $800{ }^{\circ} \mathrm{C}$ with heating time from $20 \mathrm{~s}$ to $240 \mathrm{~s}$.

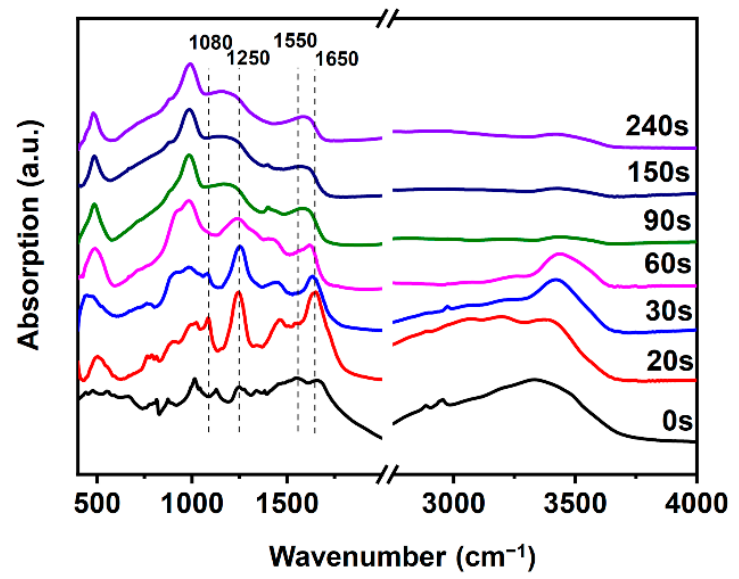

Figure 8. FTIR spectra of A3P1 resin and its char formed at $800^{\circ} \mathrm{C}$ with different heating time.

\section{Conclusions}

The A3P1 based on amino resin showed an excellent flame retardancy for wood materials. It was observed that the rise of the HRR curve is related to the cracks in intumescent char. The volume of intumescent char increased first and then decreased. The evolution of intumescent char at $800{ }^{\circ} \mathrm{C}$ could be divided into three stages:

1. The char was formed before $30 \mathrm{~s}$;

2. The volume of char decreased rapidly from $30 \mathrm{~s}$ to $90 \mathrm{~s}$;

3. The volume of char decreased slowly after $90 \mathrm{~s}$. More than $50 \%$ shrinkage of char was developed in the second stage due to the collapse of big pores (D > $5 \mathrm{~mm}$ ). 
The morphology of char was transformed from a multi-bubble structure into a sheet structure in the char formation stage. According to the results of FTIR, most of the reactions of decomposition and hydration in the char formation were completed in the first stage. The formation of the benzene ring is the main change in the second stage. The char containing the $\mathrm{P}-\mathrm{O}-\mathrm{C}$ band was formed in the third stage. It is possible to improve the properties of flame-retardant coatings based on a good understanding the evolution of intumescent char.

Author Contributions: Conceptualization, W.Q. and Y.W.; methodology, W.S., M.W., Y.H., and W.Q.; writing - original draft preparation, W.S. and W.Q.; writing — review and editing, W.Q.; supervision, Y.W.; funding acquisition, W.Q. and Y.W. All authors have read and agreed to the published version of the manuscript.

Funding: This research was funded by the National Natural Science Foundation of China (No. 31890772, 31600456, and 31570549).

Institutional Review Board Statement: Not Applicable.

Informed Consent Statement: Not Applicable.

Data Availability Statement: The data presented in this study are available on request from the corresponding author.

Acknowledgments: The authors are grateful for the support of the Flame Retardant Center of Beijing Institute of Technology and the Analytical Instrumentation Center of Peking University.

Conflicts of Interest: The authors declare no conflict of interest.

\section{References}

1. Weil, E.D. Fire-Protective and Flame-Retardant Coatings-A State-of-the-Art Review. J. Fire Sci. 2011, 29, 259-296. [CrossRef]

2. Duquesne, S.; Magnet, S.; Jama, C.; Delobel, R. Thermoplastic resins for thin film intumescent coatings-towards a better understanding of their effect on intumescence efficiency. Polym. Degrad. Stab. 2005, 88, 63-69. [CrossRef]

3. Gu, J.-W.; Zhang, G.-C.; Dong, S.-L.; Zhang, Q.-Y.; Kong, J. Study on preparation and fire-retardant mechanism analysis of intumescent flame-retardant coatings. Surf. Coat. Technol. 2007, 201, 7835-7841. [CrossRef]

4. Jiao, C.; Chen, X. Flammability and thermal degradation of intumescent flame-retardant polypropylene composites. Polym. Eng. Sci. 2010, 50, 767-772. [CrossRef]

5. Lu, H.; Song, L.; Hu, Y. A review on flame retardant technology in China. Part II: Flame retardant polymeric nanocomposites and coatings. Polym. Adv. Technol. 2011, 22, 379-394. [CrossRef]

6. Puri, R.G.; Khanna, A.S. Intumescent coatings: A review on recent progress. J. Coat. Technol. Res. 2017, 14, 1-20. [CrossRef]

7. Battegazzore, D.; Alongi, J.; Fontaine, G.; Frache, A.; Bourbigot, S.; Malucelli, G. Bulk vs. surface flame retardancy of fully bio-based polyamide 10,10. RSC Adv. 2015, 5, 39424-39432. [CrossRef]

8. Xu, Z.; Chu, Z.; Yan, L.; Chen, H.; Jia, H.; Tang, W. Effect of chicken eggshell on the flame-retardant and smoke suppression properties of an epoxy-based traditional APP-PER-MEL system. Polym. Compos. 2019, 40, 2712-2723. [CrossRef]

9. Wang, Z.; Han, E.; Ke, W. Effect of acrylic polymer and nanocomposite with nano-SiO2 on thermal degradation and fire resistance of APP-DPER-MEL coating. Polym. Degrad. Stab. 2006, 91, 1937-1947. [CrossRef]

10. Jimenez, M.; Bellayer, S.; Revel, B.; Duquesne, S.; Bourbigot, S. Comprehensive Study of the Influence of Different Aging Scenarios on the Fire Protective Behavior of an Epoxy Based Intumescent Coating. Ind. Eng. Chem. Res. 2013, 52, 729-743. [CrossRef]

11. Gravit, M.; Gumenyuk, V.; Sychov, M.; Nedryshkin, O. Estimation of the Pores Dimensions of Intumescent Coatings for Increase the Fire Resistance of Building Structures. Procedia Eng. 2015, 117, 119-125. [CrossRef]

12. Gao, M.; Pan, D.X.; Sun, C.Y. Study on the thermal degradation of wood treated with amino resin and amino resin modified with phosphoric acid. J. Fire Sci. 2003, 21, 189-201. [CrossRef]

13. Ma, X.-X.; Wu, Y.-Z.; Zhu, H.-L. The fire-retardant properties of the melamine-modified urea-formaldehyde resins mixed with ammonium polyphosphate. J. Wood Sci. 2013, 59, 419-425. [CrossRef]

14. Horrocks, A.R.; Kandola, B.K.; Davies, P.J.; Zhang, S.; Padbury, S.A. Developments in flame retardant textiles-A review. Polym. Degrad. Stab. 2005, 88, 3-12. [CrossRef]

15. Vroman, I.; Giraud, S.; Salaun, F.; Bourbigot, S. Polypropylene fabrics padded with microencapsulated ammonium phosphate: Effect of the shell structure on the thermal stability and fire performance. Polym. Degrad. Stab. 2010, 95, 1716-1720. [CrossRef]

16. Alongi, J.; Han, Z.; Bourbigot, S. Intumescence: Tradition versus novelty. A comprehensive review. Prog. Polym. Sci. 2015, 51, 28-73. [CrossRef]

17. Wang, Z.; Han, E.; Ke, W. Influence of expandable graphite on fire resistance and water resistance of flame-retardant coatings. Corros. Sci. 2007, 49, 2237-2253. [CrossRef] 
18. Zhang, Y.; Wang, Y.C.; Bailey, C.G.; Taylor, A.P. Global modelling of fire protection performance of intumescent coating under different cone calorimeter heating conditions. Fire Saf. J. 2012, 50, 51-62. [CrossRef]

19. Wang, Z.; Han, E.; Ke, W. Influence of nano-LDHs on char formation and fire-resistant properties of flame-retardant coating. Prog. Polym. Sci. 2005, 53, 29-37. [CrossRef]

20. Gu, H.; Guo, J.; He, Q.; Tadakamalla, S.; Zhang, X.; Yan, X.; Huang, Y.; Colorado, H.A.; Wei, S.; Guo, Z. Flame-Retardant Epoxy Resin Nanocomposites Reinforced with Polyaniline-Stabilized Silica Nanoparticles. Ind. Eng. Chem. Res. 2013, 52, 7718-7728. [CrossRef]

21. Amir, N.; Ahmad, F.; Megat Yusoff, P.S.M. Char Strength of Wool Fibre Reinforced Epoxy-Based Intumescent Coatings (FRIC). Adv. Mater. Res. 2013, 626, 504-508. [CrossRef]

22. Toldy, A.; Szolnoki, B.; Marosi, G. Flame retardancy of fibre-reinforced epoxy resin composites for aerospace applications. Polym. Degrad. Stab. 2011, 96, 371-376. [CrossRef]

23. ISO 5660-1, Reaction-to-Fire Tests-Heat Release, Smoke Production and Mass Loss Rate-Part. 1: Heat Release Rate (Cone Calorimeter Method); Internationan Organization for Standardization: Geneva, Switzerland, 2002.

24. Park, S.B.; Lee, M.; Son, D.W.; Lee, S.M.; Kim, J.I. Fire performance of carbonized medium density fiberboard manufactured at different temperatures. J. Wood Sci. 2014, 60, 74-79. [CrossRef]

25. Mariappan, T. Recent developments of intumescent fire protection coatings for structural steel: A review. J. Fire Sci. 2016, 34, 120-163. [CrossRef]

26. JIS A 1321:1994, Testing Method for Incombustibility of Internal Finish Material and Procedure of Buildings; Japanese Standards Association: Tokyo, Japan, 1994.

27. Wang, L.L.; Wang, Y.C.; Yuan, J.F.; Li, G.Q. Thermal conductivity of intumescent coating char after accelerated aging. Fire Mater 2013, 37, 440-456. [CrossRef]

28. Li, G.X.; Yang, J.F.; He, T.S.; Wu, Y.H.; Liang, G.Z. An Investigation of the thermal degradation of the intumescent coating containing MoO3 and Fe2O3. Surf. Coat. Technol. 2008, 202, 3121-3128. [CrossRef]

29. Davies, P.J.; Horrocks, A.R.; Miraftab, M. Scanning electron microscopic studies of wool/intumescent char formation. Polym. Inter. 2000, 49, 1125-1132. [CrossRef]

30. Zhang, R.; Xiao, X.; Tai, Q.; Huang, H.; Hu, Y. Modification of lignin and its application as char agent in intumescent flameretardant poly(lactic acid). Polym. Eng. Sci. 2012, 52, 2620-2626. [CrossRef]

31. Pan, H.; Wang, W.; Pan, Y.; Song, L.; Hu, Y.; Liew, K.M. Formation of self-extinguishing flame retardant biobased coating on cotton fabrics via Layer-by-Layer assembly of chitin derivatives. Carbohyd. Polym. 2015, 115, 516-524. [CrossRef]

32. Fang, F.; Zhang, X.; Meng, Y.; Gu, Z.; Bao, C.; Ding, X.; Li, S.; Chen, X.; Tian, X. Intumescent flame retardant coatings on cotton fabric of chitosan and ammonium polyphosphate via layer-by-layer assembly. Surf. Coat. Tech. 2015, 262, 9-14. [CrossRef]

33. Lai, X.; Qiu, J.; Li, H.; Zhou, R.; Xie, H.; Zeng, X. Thermal degradation and combustion behavior of novel intumescent flame retardant polypropylene with N-alkoxy hindered amine. J. Anal. Appl. Pyrol. 2016, 120, 361-370. [CrossRef] 